
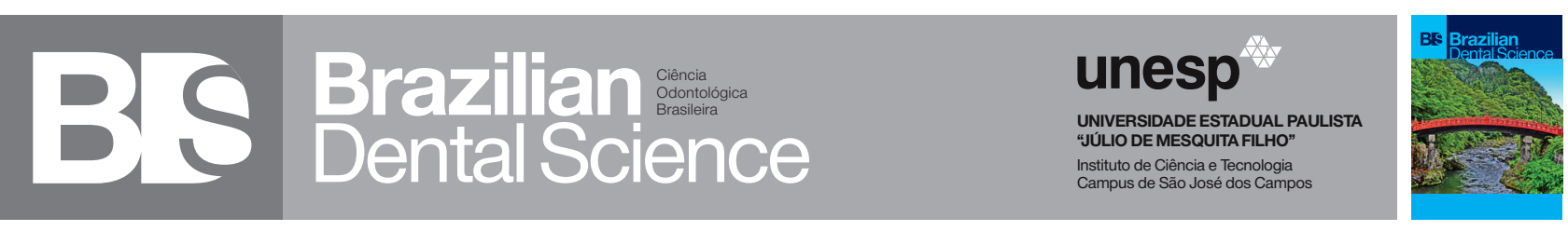

\title{
(i)
}

\section{Impaction of primary tooth molar in mandibule - case report}

\author{
Primeiro molar decíduo impactado em mandíbula - relato de caso
}

Cleverson PATUSSI', Larissa Balbo ZAVAREZ ${ }^{2}$, Guilherme Klein PARISE ${ }^{2}$, Juliana Lucena SCHUSSEL ${ }^{2}$, Laurindo Moacir SASSI ${ }^{2}$

1 - Universidade Federal do Paraná - Cirurgia Bucomaxilofacial - Curitiba - PR - Brazil.

2 - Erasto Gaertner Hospital - Oral Maxillofacial Surgery - Curitiba - PR - Brazil.

\begin{abstract}
Tooth impaction results from a mechanical blocking that prevents the tooth from erupt. This situation is frequently associated to permanent tooth as wisdom teeth and canines. Impaction of a primary tooth can be associated to systemic or local etiologic factors. Treatment options could include dental extraction, removal of lesion associated without removing the primary tooth and others. The aim of this article is to present a rare case report of an impacted primary tooth in a 42 yearold man, with no complain of swelling. Extra oral examination revealed no alteration of normality. The panoramic radiograph showed a primary tooth impacted in the left body of the mandible. Most of the time the cause for non-eruption of primary tooth is the presence of a mechanical obstacle, not anatomical, in its trajectory. The surgical intervention is a possibility, but it can stay unaltered with no problems related to the impacted tooth. Many times the professional experience and the activity together in various areas of knowledge are the most important and wise conduct to be taken in health care.
\end{abstract}

\section{KEYWORDS}

Mandible; Impacted tooth; Oral surgery.

\section{RESUMO}

A impactação dental resulta de um bloqueio mecânico que impede o dente de erupcionar. Esta situação está frequentemente associada à dentes permanentes como os terceiros molares e os caninos. Impactação de um dente decíduo pode estar associada a fatores sistêmicos ou locais. Opções de tratamento podem incluir extração dental, remoção da lesão associada sem remoção do dente decíduo, entre outros. O objetivo deste artigo é apresentar um raro relato de caso de um dente decíduo impactado em um paciente do gênero masculino, 42 anos de idade, sem queixas de inchaço. A avaliação extra-bucal não mostrou alterações de normalidade. A radiografia panorâmica evidenciou um dente decíduo impactado em corpo de mandíbula, lado esquerdo. Na maioria dos casos a causa para não erupção de um dente decíduo é a presença de um obstáculo mecânico, não anatômico, em sua trajetória de erupção. A intervenção cirúrgica é uma possibilidade, mas pode permanecer inalterada sem problemas relacionados ao dente impactado. Em muitos casos a experiência profissional e a atividade em conjunto com várias áreas do conhecimento são as condutas mais importantes e sábias a serem tomadas no cuidado em saúde.

\section{PALAVRAS-CHAVE}

Mandíbula; Dente impactado; Cirurgia oral.

\section{INTRODUCTION}

$\mathrm{T}_{\mathrm{s}}^{\mathrm{o}}$ ooth impaction results from a mechanical blocking that prevents the tooth from erupt in its chronological time [1]. This situation is frequently associated to permanent tooth as wisdom teeth and canines. [2-4] Moreover, primary tooth impaction is a rare condition during the development of primary dentition [5]. The presence of primary tooth impacted in an adult with complete permanent dentition with no other medical condition associated has never been reported in international literature until now. 
Impaction of a primary tooth can be associated to systemic or local etiologic factors such as anklyosis, permanent teeth agenesis, defects in the periodontal membrane, trauma, injury of the periodontal ligament, early eruption of the permanent tooth, defective eruptive force, presence of pathological lesions associated to the teeth, genetic predisposition, environmental factors or a combination of these factors. [1,6-7]

The treatment depends on impacted tooth location, association or not with a pathology, patient agreement, clinical and medical condition, technical aspects of the surgery, patient age, comorbidities, aesthetic features, history of infection, pain or others symptoms that may be related to the impacted tooth. [5]

Treatment options could include dental extraction, removal of lesion associated without removing the primary tooth, removal of lesion with the primary tooth at the same surgical procedure, dental traction and ulotomy. Nonetheless, each case requires a specific evaluation with clinical examination and detailed image exams to choose the gold standard treatment. $[1,8,9]$

The aim of this article is to present a rare case report of an impacted primary tooth in a 42 year-old man, with no similar reports in English scientific literature.

\section{CASE REPORT}

Male patient, 42 years-old, presented to routine dental appointment with no complain of swelling, pain or other disorder in oral cavity. The medical history did not suggest noteworthy. No signs or symptoms of syndromes were evident and he had no history of dental trauma or infection.

Extra oral examination revealed no alteration of normality. During intra oral examination, it was observed the absence of some teeth and the presence of caries and old filings. Patient reported that he had never done radiography images of the mandible and maxilla, as a panoramic radiograph.

The panoramic radiograph showed a primary tooth impacted in the left body of the mandible. The primary tooth was located on the lower part of the mandible, near to the inferior limit of the bone in the premolar area between the teeth 34 and 35 that are fully erupted and in function in the oral cavity. It was possible to note that tooth 35 was in slightly infra occlusion. No bone alteration was detected and no lesion or alteration that could prevent the eruption of the primary tooth was noted. (Figure 1) The patient was unaware of the presence of anomalies in dental chronology in his family, or any other familiar disease associate to oral cavity or dental conditions.

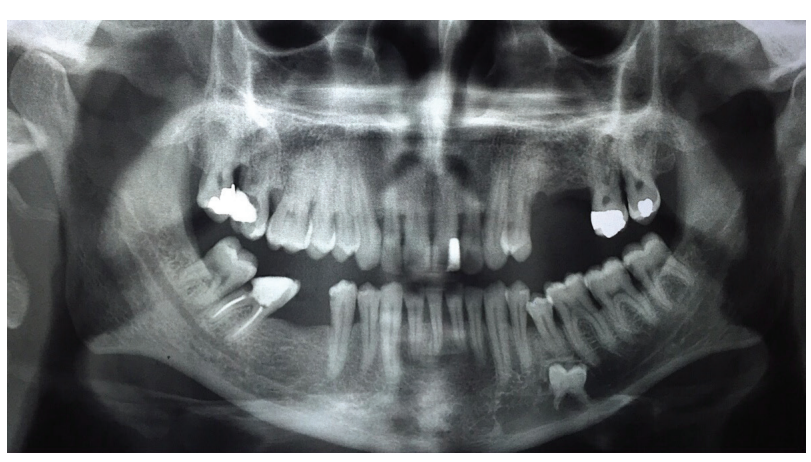

Figure 1 - Panoramic radiographic demonstrating impaction of the deciduous tooth in the left mandible body.

\section{DISCUSSION}

Eruption is a continuous process of the tooth from its developmental location to its functional location. Interference in the eruption process creates a clinical situation that can be challenging to diagnose and treatment. The spectrum of tooth eruption disorders includes both syndromic and nonsyndromic conditions that can cause delayed eruption and/or complete failure of eruption.

Failure of permanent teeth to erupt without obvious etiology is a rare dental anomaly. It is called tooth impaction situations where failure of eruption occurs by physical barrier (impacted) or when a lack of eruptive force (embedded) appears to be caused by a barrier and the tooth remains unerupted. The impaction can be caused by systemic or local etiologic factors [1,7]. 
Most of the time the cause for non-eruption of primary tooth is the presence of a mechanical obstacle, not anatomical, in its trajectory. It is fairly described in literature the association of lesions suchs as odontogenic tumors, cysts and non-neoplastic proliferative lesions (odontoma, cementoblastoma, adenomatoid odontogenic tumor, radicular cysts) with impacted primary teeth $[2,6,10-13]$. Chronology may be modified by factors already discussed, and primary tooth remains impacted by the presence of permanent tooth that have a premature eruption. [14-16]

One other differential diagnosis and condition that must be lead to mention is the retained deciduous teeth. This is a condition where the absence of the primary tooth occurs by the infraocclusion disorder of these organ observed mainly in deciduous primary molars. The ankylosed infraoccluded tooth is positioned below the occlusal plane in a variety of vertical discrepancies, causing a challenging malocclusion for which a multidisciplinary treatment approach is often required. [17,18] Until recently, the etiology of infraocclusion is unclear but a familial relation, as well as an association with other dental anomalies, has been reported, suggesting a shared genetic origin with main cause of this disorder. Differently if compare whit impacted deciduous teeth that are mostly etiological connected to local factors.

It is important to identify different anomalies and conditions to ensure the correct diagnosis and as a consequence the best approach to be adopted. Many conditions already have specific treatments discussed in the literature with high scientific evidence indices, with no relevant or contradictory questions related $[10,13]$. Moreover, the case described it does not fit into any classifications of diseases or conditions discussed in the literature. The patient presented the primary tooth included had no injuries or included permanent teeth associated, no history of previous trauma or infection in the region, the tooth was not in infra occlusion and no syndrome could be associated to dental impaction.

The lack of similar cases reported in literature also reflects in the doubts about best approach. The question about whether theremoval or not of asymptomatic impacted teeth is always discussed by Oral and Maxillofacial surgeons, as some might argue the financial factor, the risk of surgical complications, postoperative discomfort and the absence of scientific evidence of removal of asymptomatic teeth included are bases for the conservative treatment. [19]. Cochrane library, which is considered the scientific basis of higher value and level of evidence through systematic review, addressed these specific clinical question - perform or not removal of included tooth in adult patients. The reviewers concluded "no evidence was found to support or refute routine prophylactic removal of asymptomatic impacted wisdom teeth in adults." [20] Authors that supports of both management strategies have used this review to base their positions. Reports of best approach in cases like described in this article are rare or inexistent; therefore the authors used the Cochrane evidence to basis the decision an conduct approach.

Furthermore, it was decided to follow up the patient with periodic radiographs for evaluation of impacted tooth. The decision took into account the same principles of nonsurgical intervention of dental extraction in older patients who never had any comorbidity or problems related to the impacted tooth, wisdom or any other $[19,20]$. It should be important consider that surgical intervention is a possibility, but it can stay unaltered with no problems related to the impacted tooth. The surgical risk and possible complications and consequences of surgery such as mandibular fractures, transient or permanent paresthesia, postoperative comorbidities, anesthetic risks can avoided with conservative treatment. A situation that the authors would consider plausible for removal of impacted tooth is the 
eventual extraction of the tooth 35 associated with dental implant indication.

The clinical management in such cases should be performed with scientific foundation in a high standard, with the help of quality imaging and the presence of a multidisciplinary team aware and willing to study the treatment in a specific case, leading to a gold standard treatment. Many times the professional experience and the activity together in various areas of knowledge are the most important and wise conduct to be taken in health care, especially when are discussed rarely or information about the situation is poor or even inexistent.

\section{REFERENCES}

1. Counihan K, Al-AwadhiEA, Butler J. Guidelines for the assessment of the impacted maxillary canine. Dent Update. 2013 Nov;40(9): 770-2, 775-7.

2. Kaczor-Urbanowicz K,ZadurskaM, CzochrowskaE. Impacted Teeth: An Interdisciplinary Perspective. Adv Clin Exp Med. 2016 May-Jun;25(3):575-85. doi: 10.17219/acem/37451.

3. Jung $\mathrm{YH}, \mathrm{Cho}$ BH. Prevalence of missing and impacted third molars in adults aged 25 years and above. Imaging Sci Dent. 2013 Dec;43(4):219-25. doi: 10.5624/isd.2013.43.4.219.

4. Sajnan AK. Permanent maxillary canines - review of eruption pattern and local etiological factors leading to impaction. J Investig Clin Dent. 2015 Feb;6(1):1-7. doi: 10.111//jicd.12067.Epub2013 Dec 20.

5. Yadiki JV,Kategari YB, Chada P,Vallakatla V.Can Milk Teeth be Impacted? Why Not: A Case of Six impacted Primary Teeth. Int J Clin Pediatr Dent. 2014 Sep-Dec;7(3):220-2.

6. Balaji SM. Submerged mandibular carious deciduous second molar along with an impacted second premolar associated with an atypical inflammatory follicular cyst: A rare case report. Indian J DentRes. 2013 Nov-Dec;24(6):775-9. doi: 10.4103/0970-9290.127634.

7. Vani S, Nooney A, Raju KS, Hemadri M. Idiopathic multiple unerupted permanent teeth: A rare case report. J Dr.NTR University Health Sci. 2014;3(4):283-6.
8. Atwan S, DesRosiers D. Infraocclusion of lower primary molar with other familial dental anomalies: report of case. ASDC J Dent Child. 1998;65:272-5, 230.

9. Polder BJ, Van't Hof MA, Van der Linden FP,Kuijpers-Jagtman AM. A metaanalysis of the prevalence of dental agenesis of permanent teeth. Community Dent Oral Epidemiol. 2004 Jun;32(3):217-26.

10. Tecco S, Lacarbonara M, Dinoi MT, Gallusi G, Marchetti E, Mummolo S, etal. The retrieval of unerupted teeth in pedodontics: two case reports. J Med Case Rep. 2014 0ct 9;8:334. doi: 10.1186/1752-1947-8-334.

11. Kjaer I. Mechanism of human tooth eruption: review article including a new theory for future studies on the eruption process. Scientifica. 2014.341905. 10.1155/2014/341905.

12. Monti LM, Souza AM, Soubhia AM, Jorge WA, Anichinno M, Da Fonseca GL Cementoblastoma: a case report in deciduous tooth. Oral Maxillofac Surg.2013 Jun;17(2):145-9. doi:10.1007/s10006-012-0347-4.

13. Uloopi KS, Shivaji RU, Vinay C; Pavitra, Shrutha SP,Chandrasekhar R Conservative management of large radicular cysts associated with non-vital primary teeth: a case series and literature review. J Indian Soc Pedod Prev Dent. 2015 Jan-Mar;33(1):53-6.

14. Memarpour M, Rahimi M, Bagheri A, Mina K. Unerupted Primary Molar Teeth Positioned Inferior to the Permanent Premolar: A Case Report. J Dent (Tehran). 2012 Winter;9(1):79-82.

15. Rasmussen P,Kotsaki A. Inherited primary failure of eruption in the primary dentition: report of five cases. ASDC J Dent Child. 1997 Jan-Feb;64(1):43-7.

16. Ferro R,Besostri A, Stellini E, Denotti G, Canesso A. A rare case of unerupted second deciduous molar located inferior to the second premolar: case report. Eur J Paediatr Dent. 2012Sep;13(3):236-8.

17. Shalish M, Har-Zion G,Zini A, Harari D, Chaushu S. Deep submersion: Severe phenotype of deciduous-molar infraocclusion with biological associations. Angle Orthod. 2014 Mar;84(2):292-6. doi: 10.2319/060913-436.1.

18. Shalish M, Har-Zion G,Zini A, Harari D, Chaushu S. Deep Submersion: Severe phenotype of deciduous-molar infraocclusion with biological associations. Angle Orthod. 2014 Mar;84(2):292-6. doi: 10.2319/060913-436.1.

19. Boughner JC. Maintaining perspective on third molar extraction. J Can Dent Assoc. 2013;79:d106.

20. Dodson TB. The management of the asymptomatic, disease-free wisdom tooth: removal versus retention. Atlas Oral Maxillofac Surg Clin North Am. 2012 Sep;20(2):169-76. doi:10.1016/j.cxom.201206.005.

\section{Cleverson Patussi}

